\title{
Delayed response of epididymal sperm characteristics and testicular oxidative stress following EGME exposure: Ameliorating potential of Withania somnifera root extract
}

\author{
Praveen Kumar, Poonam Singh \\ Department of Zoology, MMV, Banaras Hindu University, Varanasi, U.P., 221005, India.
}

\begin{tabular}{|c|c|}
\hline ARTICLE INFO & ABSTRACT \\
\hline $\begin{array}{l}\text { Article history: } \\
\text { Received on: } 12 / 09 / 2017 \\
\text { Accepted on: } 16 / 12 / 2017 \\
\text { Available online: } 28 / 01 / 2018\end{array}$ & $\begin{array}{l}\text { Swiss strain male mice were administered orally with ethylene glycol monomethyl ether (EGME) for } 6 \text { and } 10 \text { days } \\
\text { and studied the epididymal sperm characteristics and testicular oxidative stress } 24 \text { hours after each duration. With- } \\
\text { drawal study on the same parameters was carried out } 20 \text { and } 45 \text { days after the mice received EGME for } 10 \text { consecutive } \\
\text { days. Efficacy of Withania somnifera }(W s) \text { root extract was also studied in the mice received EGME for } 10 \text { days only, } \\
\text { followed by oral administration of WS, from } 11^{\text {th }} \text { day to } 30^{\text {th }} \text { day. Treatment with } W s \text { root extract was then terminated }\end{array}$ \\
\hline $\begin{array}{l}\text { Key words: } \\
\text { Ethylene glycol monomethyl } \\
\text { ether, Withania somnifera, } \\
\text { Epididymis, Sperm, } \\
\text { oxidative stress. }\end{array}$ & $\begin{array}{l}\text { and studied the effects on } 31^{\text {st }} \text { day. EGME treatment for } 6 \text { and } 10 \text { consecutive days did not cause significant alterations } \\
\text { in the percentage of motile, viable, count and abnormal spermatozoa in the epididymis as well as the oxidative stress } \\
\text { in the testis. However significant reductions were noted in these sperm indices with a significant increase in abnormal } \\
\text { spermatozoa in the epididymis of } 20 \text { days EGME-withdrawal group. Oxidative stress in the testis of the mice of the } \\
\text { same group was also elevated as evidenced by significant reductions in the activities of antioxidant enzymes (SOD, } \\
\text { catalase and GPX) and increase in lipid peroxidation. Forty five days after withdrawal of the treatment, as well as } \\
\text { supplementation with } W s \text { for } 20 \text { days in } 10 \text { days EGME-treated mice resulted in significant reinstatement in these } \\
\text { parameters. The study suggested that the toxicity of EGME noticed during early treatment withdrawal period, may be } \\
\text { prevented by } W s \text { root extract therapy. }\end{array}$ \\
\hline
\end{tabular}

\section{INTRODUCTION}

The glycol ethers represent a diverse series of compounds having properties which make them widely suited for a variety of solvent applications. They are used in industries as jet fuel deicers, photography, inks and coatings, dyeing and in the manufacture of plasticizers and printed circuit boards. Among ethylene glycol ethers, ethylene glycol monomethyl ether (EGME; 2-methoxyethanol) is a widely used solvent in semiconductor, chemical and food industries. It is also used in dyeing leather. A lot of literature is available regarding toxicity of EGME in various species. It has been reported that rapidly dividing cells with high metabolism are more vulnerable to EGME-treatment (Johanson, 2000; Boatman, 2005; Bagchi and Waxman, 2008). Rapidly divid-

${ }^{*}$ Corresponding Author

Poonam Singh, Professor, Dept. of Zoology, MMV, Banaras Hindu University, Varanasi U.P., 221005, India.

E-mail:poonom@gmail.com ing cell systems such as bone marrow, thymus, spleen and testicular epithelium germ cells appear to be the primary target organs following exposure to EGME. Wiley et al. (1938) were the first to report that treatment with EGME causes damage to the testis of rabbit. This observation has been confirmed and extended by several authors (Watanabe et al., 2000, Boatman, 2001; Boatman and Knaak, 2001; Multigner et al., 2005). EGME is considered as the most potent toxicological alkyl ether inducing testicular damage in the rat (Watanabe et al., 2000) and has noticeable adverse effects on sperm concentration and quality in the rat, mouse and rabbit (Boatman, 2001; Boatman and Knaak, 2003; Multigner et al., 2005). It adversely affects the mating performance and impairs the epididymal sperm characteristics in the rat (Wang et al., 2006). There are few reports suggesting that EGME-induced testicular toxicity is mediated through the inhibitor of primary flavoprotein dehydrogenases (Takei et al., 2010) and oxidative stress (Bagchi and Waxman, 2008). The preventing approach for such induced 
toxicities using herbal extracts has become a major area of concern in the reproductive health. Several medicinal plants have been used in the treatment of stress-induced infertility. Medicinal plants like Asparagus racemosus, Bacopa monnieri, Phyllanthus emblica, Withania somnifera, Tribulus terrestris etc. are widely reported for their antioxidant properties (Chaurasia et al., 2000; Staugh et al., 2001; Zheleva-dimitrova et al., 2012).

Protective effects of some medicinal plants have also been reported against ethylene glycol-induced toxicity in rats. Rubia cardifolia protects the Ethylene glycol-induced nephrotoxicity. Adepu et al. (2015) and Lulat et al. (2016) studied the antiurolithiatic effect of Alternanthera tenella colla and lithocare against ethylene glycol-induced urolithiasis in rats, respectively. Antioxidant properties of biflavonoid kolaviron, from the seed of Garcinia kola has been reported against ethylene glycol monoethyl ether (EGEE)-induced reproductive toxicity in male rats by reducing the oxidative stress and improving the quality and quantity of spermatozoa (Adedara and Farombi, 2012).

Withania somnifera $(W s)$, is one of the members of generally regarded as safe category of plants that can be used for the therapeutic purposes (Bolleddula et al., 2003). It is one of the traditional medicinal plant, widely used in Ayurvedic medicine system of India. It is also known 'as Ashwagandha, Indian ginseng and winter cherry. Charak Sanghita mentions the therapeutic importance of its different parts. This plant contains several biologically active chemical constituents such as alkaloids (isopellertierine, anferine), steroidal lactones (withanolides, withaferins), saponins and withanolides. Historically, this plant has been used as an adaptogen, aphrodisiac, antioxidant, liver tonic, astringent, anti-inflammatory agent and more recently to treat ulcers, venom toxins, bacterial infection, and senile dementia (Singh et al., 2010). Reports of Ilayperum and co-authors (2002) have suggested the use of $W s$ for the treatment of libido, inflammation, anxiety, Parkinson's disease, cognitive and neurological disorders. Archana and co-authors (1999) have reported the adaptogenic and antistressor properties of Ws. It also possesses anti-oxidantive properties (Bhattacharya et al., 2001; Jaleel et al., 2008).

The root of $W S$ contains several alkaloids, withanolides, flavonoids and reducing sugars (Umadevi, 1996). More than 20 active constituents have been reported to date, including withaferin A, sitoindosides VII-X, withanosides I-VII, choline, and $\beta$-sitosterol (Ganzera et al., 2003). The root extract of $W_{S}$ has been shown to have anti-stress, anti-inflammatory, anti-arthiritic, anti-pyretic, analgesic, anti-oxidant and immunomodulatory properties (Dhuley, 2000; Davis and Kuttan, 2002; Prakash et al., 2002; Gupta et al., 2003). Ameliorating potential of $W S$ has also been reported against arsenic, in impairing fertility of the males (Kumar et al., 2015). Further, $W s$ also improves galactose-induced stress in the rat (Patil et al., 2012).

Due to presence of richest natural sources of bioactive compounds in the whole root of $W s$, reputed for its antioxidant potential, its extract has been planned to be used for the proposed study. Further no studies have been reported regarding the efficacy of $W s$ on EGME-induced reproductive toxicity in the males. Thus, the present study deciphers the ameliorating potentiality of the root extract of Withania somnifera on the epididymal sperm characteristics and testicular oxidative stress in Ethylene Glycol Monomethyl Ether-exposed mice.

\section{MATERIALS AND METHODS}

\section{Preparation of plant extract}

The roots of Withania somnifera were collected from local market of Varanasi, got identified in the Department of Botany, BHU, Varanasi, India. The roots were cleaned, washed with distilled water and blotted with blotting paper. They were shade dried and crushed in electric grinder to make the coarse powder. The coarse powder was extracted with $70 \%$ ethanol $(1: 10)$ in a Soxhlet apparatus and then dried at reduced pressure. The extract was stored at $4{ }^{\circ} \mathrm{C}$ in air tight bag and dissolved in distilled water for animal treatment.

\section{Animals}

Thirty adult male mice of Swiss strain were used in the present study. The animal study protocol was approved by the Animal Ethical Committee, BHU, Varanasi (F.Sc./ IAEC/2014-15/0333). The animals were maintained in well ventilated room at 12 hours light and 12 hours dark. They were fed with pelleted food and drinking water ad libitum. The initial body weight of all the animals was recorded.

\section{Experimental design}

The animals were divided into six groups of five each. Mice of Group I served as vehicle-treated control. EGME (600 $\mathrm{mg} / \mathrm{kgBW} /$ day) was administered in Groups II and III for 6 and 10 consecutive days, respectively. Mice in Group IV and $\mathrm{V}$ were administered with same dose of EGME for 10 consecutive days and sacrificed 20 and 45 days after withdrawal of the treatment. Animals of Group VI were administered with EGME (600 mg/kgBW/day) for 10 days and then administered with $W s(100 \mathrm{mg} / \mathrm{kgBW} /$ day $)$ only for 20 days that is from $11^{\text {th }}$ to $30^{\text {th }}$ day, followed by their sacrifice on $31^{\text {st }}$ day. EGME and $W s$ were dissolved in double distilled water and administered through oral rout. Twenty four hours after the last treatment, final body weight of the animals was recorded and euthanized by cervical dislocation. The testis and epididymis were dissected out soon after euthanization, cleared of fat and washed with saline. The testis was stored in the deep freezer for estimation of antioxidant enzymes while the epididymis was used for the sperm assessment immediately following the sacrifice.

\section{Epididymal sperm assessment}

Cauda epididymidis was minced thoroughly in the normal saline $(0.9 \% \mathrm{NaCl})$ at $37^{\circ} \mathrm{C}$ and the suspension was then used for sperm analysis according to WHO laboratory manual (2010).

\section{Sperm motility}

The sperm motility was observed immediately under the microscope at $40 \mathrm{X}$ by placing a drop of prepared sperm suspension on the pre-warmed slide and covered with the prewarmed coverslip. Spermatozoa showing any degree of movement were considered to be motile. More than one hundred spermatozoa were observed to calculate the percentage motility. 


\section{Sperm viability}

The viability of spermatozoa was studied by preparing smear of a drop of suspension using supra-vital staining technique with eosin-nigrosin stain. About one hundred spermatozoa including viable and dead, were scored from different region of the smear prepared on the slide to calculate the viability percentage. Spermatozoa appearing pinkish were considered dead, while those appearing colourless as viable.

\section{Sperm count}

A twenty fold dilution was made by mixing the sperm suspension with the spermicidal solution $\left(\mathrm{NaHCO}_{3}: 4 \mathrm{~g}+\right.$ phenol: $1 \mathrm{~g}$ in $100 \mathrm{ml}$ of distilled water). A haemocytometer with improved Neubauer ruling was used for counting the spermatozoa.

\section{Sperm morphology}

For evaluation of the sperm morphology, same suspensions as used for the viability test, were examined. Evaluation of sperm abnormality was based on the criteria of Wyrobek and Bruce (1975) and Zaneveld and Polakoski (1977). About one hundred spermatozoa both normal and abnormal were counted from different fields to calculate the percentage abnormality.

\section{Homogenate preparation}

Ten percent $(\mathrm{w} / \mathrm{v})$ homogenate of the testis was prepared with the aid of $50 \mathrm{mM}$ phosphate buffer ( $\mathrm{pH}-7.0)$, as per requirement. The whole homogenate was first centrifuged at $10,000 \mathrm{Xg}$ for 20 minutes at $4^{\circ} \mathrm{C}$ (Vaithinathan et al., 2008). The supernatant was collected and kept at $-20^{\circ} \mathrm{C}$ till further investigation. The supernatant was used for the enzymes assay after estimating the protein content by the method of Lowry et al. (1951).

\section{Antioxidant enzymes analysis}

\section{Lipid peroxidation estimation}

The concentration of malonaldehyde (MDA) was measured in the supernatants by the method of Okhawa et al., (1979). The reaction mixture was prepared by adding $200 \mu \mathrm{l}$ supernatant, $100 \mu \mathrm{l}$ of $0.8 \%$ BHT (Butylated Hydroxy Toluene ), $200 \mu \mathrm{l}$ SDS (Sodium dodecyl sulphate), $1.5 \mathrm{ml}$ of $20 \%$ acetic acid and $1.5 \mathrm{ml}$ of $0.8 \%$ aqueous solution of TBA (Thiobarbituric acid). Reaction mixture was then heated at $95^{\circ} \mathrm{C}$ in water bath for 60 minutes. Then the mixture was cooled and centrifuged at $2000 \mathrm{rpm}$ for 10 minutes. Absorbance of supernatant was measured in a spectrophotometer at $532 \mathrm{~nm}$ against blank containing all the reagents except the test sample. The values were expressed as nanomole MDA produced per milligram protein.

\section{Superoxide dismutase}

Superoxide dismutase (SOD) was assayed by the method of Murklund and Marklund (1974). The assay mixture was prepared by adding $2.4 \mathrm{ml}$ of Tris - HCL $(50 \mathrm{mM})$ containing $1 \mathrm{mM}$ EDTA (pH 7.6), $300 \mu \mathrm{l}$ pyrogallol $(0.2 \mathrm{mM})$ and $100 \mu \mathrm{l}$ enzyme source. The increase in absorbance was measured immediately at $420 \mathrm{~nm}$, against blank containing all components except the enzyme source and pyrogallol, at 10 seconds interval for 3 minutes on spectrophotometer. The enzyme activity was expressed as unit per milligram protein.

Catalase

Catalase was assayed by the method of Claiborne (1985). The assay mixture contained $2.4 \mathrm{ml}$ of phosphate buffer $(50 \mathrm{mM}, \mathrm{pH} 7.0), 10 \mu \mathrm{l}$ of $\mathrm{H}_{2} \mathrm{O}_{2}(19 \mathrm{mM})$ and $50 \mu \mathrm{l}$ enzymes source. The decrease in absorbance was measured immediately at $240 \mathrm{~nm}$, against a blank containing all the components except the enzyme source, at 10 seconds interval for 3 minutes on a spectrophotometer. The enzyme activity was expressed as micromoles $\mathrm{H}_{2} \mathrm{O}_{2}$ consumed per minute per milligram protein.

\section{Glutathione peroxidase}

Glutathione peroxidase (GPx) was assayed by the method of Flohe and Gunzler (1984). Enzyme assay was carried out by pipetting $750 \mu \mathrm{l}$ of potassium phosphate buffer $(0.1 \mathrm{M}, \mathrm{pH} 7.0), 60 \mu \mathrm{l}$ of NADPH (2.25 mM in $\left.0.1 \% \mathrm{NaHCO}_{3}\right)$, $15 \mu \mathrm{l}$ of glutathione reductase $(7.1 \mu \mathrm{l} / \mathrm{ml})$ and $25 \mu \mathrm{l}$ of reduced glutathione $(11.52 \mathrm{mg} / \mathrm{ml}), 50 \mu \mathrm{l}$ of supernatant and $100 \mu \mathrm{l}$ of $\mathrm{H}_{2} \mathrm{O}_{2}$. The extinction of the sample was recorded at $340 \mathrm{~nm}$ every minute for the period of 120 seconds in a spectrophotometer. The glutathione peroxidase activity was expressed in units per milligram of protein.

\section{Statistical analysis}

The values were represented as mean \pm S.E. in each group. All the data were analyzed statistically by one way ANOVA followed by Newman-Keul's test for comparison of the groups. The values for $\mathrm{P}<0.05$ were considered significant.

\section{RESULTS}

\section{Body weight}

No significant differences were obsorved between the initial and the final body weights of the mice in any groups (Table 1).

Table 1: Effect of ethanolic extract of $W s$ on body weight of EGME intoxicated male mice.

\begin{tabular}{|c|c|c|}
\hline Groups & $\begin{array}{l}\text { Initial Body } \\
\text { Weight (g) }\end{array}$ & $\begin{array}{l}\text { Final Body } \\
\text { Weight (g) }\end{array}$ \\
\hline I: Control & $22.6 \pm 0.4$ & $24.8 \pm 0.38$ \\
\hline $\begin{array}{l}\text { II: EGME } \\
(600 \mathrm{mg} / \mathrm{kgBW} / \text { day for } 6 \text { days })\end{array}$ & $26.8 \pm 0.49$ & $27.4 \pm 0.25$ \\
\hline $\begin{array}{l}\text { III: EGME } \\
\text { (600 mg/kgBW/day for } 10 \text { days) }\end{array}$ & $25.6 \pm 1.17$ & $26.4 \pm 0.98$ \\
\hline $\begin{array}{l}\text { IV: EGME* } \\
(600 \mathrm{mg} / \mathrm{kgBW} / \text { day for } 10 \text { days) }\end{array}$ & $26.0 \pm 0.63$ & $27.2 \pm 0.49$ \\
\hline $\begin{array}{l}\text { V: EGME** } \\
(600 \mathrm{mg} / \mathrm{kgBW} / \text { day for } 10 \text { days })\end{array}$ & $24.8 \pm 1.62$ & $26.8 \pm 0.8$ \\
\hline $\begin{array}{l}\text { VI: EGME } \\
(600 \mathrm{mg} / \mathrm{kgBW} / \text { day for } 10 \text { days }) \\
+ \\
W_{S}\left(100 \mathrm{mg} / \mathrm{kgBW} / \text { day from } 11^{\text {th }} \text { to } 30^{\text {th }} \text { day }\right)\end{array}$ & $25.8 \pm 0.66$ & $27.6 \pm 0.34$ \\
\hline
\end{tabular}




\section{Sperm assessment}

No significant alterations were noticed in the motility, viability and count of epididymal spermatozoa, in the mice sacrificed 6 (Gr. II) and 10 days (Gr. III) after treatment with EGME, comparable to the control (Gr. I). Percentage of morphological abnormal spermatozoa obtained from the cauda epididymidis of the mice of Gr. II and III also remained comparable to that of the mice of Gr. I. By contrast, in the mice treated with EGME for
10 days, followed by their sacrifice 20 days after withdrawal of the treatment (Gr. IV), these sperm parameters declined significantly except that of the percentage of sperm abnormality that was elevated significantly, compared to the control. However, 45 days after withdrawal of the treatment (Gr. V) and WS supplementation from $11^{\text {th }}$ to $30^{\text {th }}$ day after 10 days EGME treatment withdrawal (Gr. VI) resulted in restoration in such sperm indices, similar to the control (Table 2).

Table 2: Effect of ethanolic extract of $W s$ on sperm parameters of EGME intoxicated mice.

\begin{tabular}{|c|c|c|c|c|}
\hline Groups & Motility (\%) & Viability (\%) & Abnormality (\%) & Count $\left(\times 10^{6}\right)$ \\
\hline I: Control & $75.40 \pm 1.03$ & $74.8 \pm 1.36$ & $20.15 \pm 1.73$ & $17.34 \pm 0.169$ \\
\hline $\begin{array}{l}\text { II: EGME } \\
(600 \mathrm{mg} / \mathrm{kgBW} / \text { day for } 6 \text { days })\end{array}$ & $72.50 \pm 1.04$ & $69.25 \pm 1.49$ & $20.25 \pm 0.854$ & $17.23 \pm 0.358$ \\
\hline $\begin{array}{l}\text { III: EGME } \\
(600 \mathrm{mg} / \mathrm{kgBW} / \text { day for } 10 \text { days })\end{array}$ & $69.60 \pm 4.58$ & $67.4 \pm 4.5$ & $18.2 \pm 0.141$ & $16.19 \pm 1.53$ \\
\hline $\begin{array}{l}\text { IV: EGME* } \\
(600 \mathrm{mg} / \mathrm{kgBW} / \text { day for } 10 \text { days })\end{array}$ & $43.83 \pm 4.57^{\mathrm{a}}$ & $46.2 \pm 2.42^{\mathrm{a}}$ & $53.82 \pm 5.03^{\mathrm{a}}$ & $5.05 \pm 1.11^{\mathrm{a}}$ \\
\hline $\begin{array}{l}\text { V: EGME** } \\
(600 \mathrm{mg} / \mathrm{kgBW} / \text { day for } 10 \text { days })\end{array}$ & $72.00 \pm 1.95^{\mathrm{b}}$ & $64.6 \pm 1.89^{b}$ & $20.2 \pm 1.02^{\mathrm{b}}$ & $15.14 \pm 2.16^{\mathrm{b}}$ \\
\hline $\begin{array}{l}\text { VI: EGME } \\
(600 \mathrm{mg} / \mathrm{kgBW} / \text { day for } 10 \text { days }) \\
+ \\
W S\left(100 \mathrm{mg} / \mathrm{kgBW} / \text { day from } 11^{\text {th }} \text { to } 30^{\text {th }} \text { day }\right)\end{array}$ & $61.40 \pm 1.23^{\mathrm{c}}$ & $62.25 \pm 1.03^{\mathrm{c}}$ & $20.05 \pm 0.288^{\mathrm{c}}$ & $19.8 \pm 0.737^{\mathrm{c}}$ \\
\hline
\end{tabular}

(Values are mean \pm SEM of five animals). Significant difference at $\mathrm{p}<0.05$ (a: I vs IV, b: IV vs V, c: IV vs VI)

* 20 days withdrawal of the treatment

** 45 days withdrawal of the treatment

\section{Antioxidant markers}

Oral administration of EGME for 6 and 10 days did not affect the level of MDA and activities of SOD, Catalase and GPx compared with the controls. However significant increase in the level of MDA with significant decrease in the activities of testicular SOD, catalase and GPx compared with the controls were noticed in the mice treated with EGME for 10 days followed by 20 days withdrawal of treatment. The altered levels of MDA, SOD, catalase and GPx were restored in the mice received EGME for 10 days followed by 45 days withdrawal of the treatment as well as in the mice supplemented with WS (100 mg/kgBW/day) for 20 days following 10 consecutive days treatment with EGME (Table 3).

Table 3: Effect of ethanolic extract of $W s$ on testicular oxidative stress of EGME intoxicated mice.

\begin{tabular}{|c|c|c|c|c|}
\hline Groups & $\begin{array}{c}\text { MDA } \\
\text { (nMoles/mg protein) }\end{array}$ & $\begin{array}{c}\text { SOD } \\
\text { (Unit/mg protein) }\end{array}$ & $\begin{array}{c}\text { Catalase } \\
(\mu \mathrm{M} / \mathrm{min} / \mathrm{mg} \text { protein })\end{array}$ & $\begin{array}{c}\text { GPx } \\
\text { (Unit/mg protein) }\end{array}$ \\
\hline I: Control & $0.203 \pm 0.011$ & $0.272 \pm 0.021$ & $17.243 \pm 3.21$ & $0.127 \pm 0.015$ \\
\hline $\begin{array}{l}\text { II: EGME } \\
(600 \mathrm{mg} / \mathrm{kgBW} / \text { day for } 6 \text { days })\end{array}$ & $0.347 \pm 0.009$ & $0.283 \pm 0.024$ & $16.259 \pm 1.714$ & $0.128 \pm 0.020$ \\
\hline $\begin{array}{l}\text { III: EGME } \\
(600 \mathrm{mg} / \mathrm{kgBW} / \text { day for } 10 \text { days })\end{array}$ & $0.333 \pm 0.018$ & $0.215 \pm 0.031$ & $17.244 \pm 1.420$ & $0.093 \pm 0.020$ \\
\hline $\begin{array}{l}\text { IV: EGME* } \\
(600 \mathrm{mg} / \mathrm{kgBW} / \text { day for } 10 \text { days })\end{array}$ & $3.910 \pm 0.099^{\mathrm{a}}$ & $0.079 \pm 0.015^{\mathrm{a}}$ & $5.935 \pm 1.096^{\mathrm{a}}$ & $0.084 \pm 0.002^{\mathrm{a}}$ \\
\hline $\begin{array}{l}\text { V: EGME** } \\
(600 \mathrm{mg} / \mathrm{kgBW} / \text { day for } 10 \text { days })\end{array}$ & $0.372 \pm 0.023^{b}$ & $0.273 \pm 0.064^{b}$ & $20.283 \pm 2.607^{b}$ & $0.139 \pm 0.007^{b}$ \\
\hline $\begin{array}{l}\text { VI: EGME } \\
(600 \mathrm{mg} / \mathrm{kgBW} / \text { day for } 10 \text { days }) \\
+ \\
W S\left(100 \mathrm{mg} / \mathrm{kgBW} / \text { day from } 11^{\text {th }} \text { to } 30^{\text {th }} \text { day }\right)\end{array}$ & $0.428 \pm 0.028^{c}$ & $0.238 \pm 0.027^{\mathrm{c}}$ & $13.899 \pm 2.591^{\mathrm{c}}$ & $0.114 \pm 0.002^{\mathrm{c}}$ \\
\hline
\end{tabular}

(Values are mean \pm SEM of five animals). Significant difference at $\mathrm{p}<0.05$ (a: I vs IV, b: IV vs V, c: IV vs VI).

* 20 days withdrawal of the treatment

** 45 days withdrawal of the treatment

\section{DISCUSSION}

Testis has an abundance of highly unsaturated fatty acid, hence is highly vulnerable to oxidative stress. The results of the present study indicate oxidative stress-induced impairment in sperm characteristics following EGME exposure and its prevention with the root extract of $W S$.

Oxidative stress results in tissues due to an imbalance between the production and removal of reactive oxygen species 
(ROS). The most prominent ROS are the superoxide anion (O2.-), hydrogen peroxide $\left(\mathrm{H}_{2} \mathrm{O}_{2}\right)$, and the hydroxyl ion $(\mathrm{OH}$.). They are playing a dual role as both deleterious and beneficial species and can be either harmful or beneficial to the living systems (Valko et al. 2007). ROS in low and limited concentration, play an important role in physiology of spermatozoa and more precisely in the acquisition of fertilizing ability by promoting the binding of spermatozoa to the zona pellucida and acrosome reaction (De Lamirande et al., 1997) and also in normal testicular physiology (Boekelheide, 2005). The harmful effect of ROS occurs when there is an overproduction of ROS along with the deficiency of enzymatic and non-enzymatic antioxidant system. The major antioxidant enzymes in mammals are SOD, catalase, and GPX, which are expressed in the testis (Maiorino et al., 2003; Ischi et al., 2005). Earlier study has marked the involvement of ROS in the infertility due to defective spermatozoa function (Aitken et al., 1987; Agarwal et al. 2014).

In the present study, no significant alterations were noticed in the oxidative status of the testis as well as the sperm characteristics in the epididymis 6 and 10 days after treatment with EGME. However, significant alterations were noticed in the same following administration of EGME for 10 days followed by their sacrifice 20 days after the treatment withdrawal. Further, significant reductions were also noticed in the percentage of epididymal spermatozoa motility and viability and count in the same, with significant increase in spermatozoa abnormalities. The results are consistent with the findings of earlier authors (Wang et al., 2006; Isaac and Ebenezer, 2010). Isaac and Ebenezer (2010) has reported a significant decrease in SOD, Catalase and GPx activities with significant increase in the MDA level in the testis of the mice exposed to EGME ( 200 and $400 \mathrm{mg} / \mathrm{kgBW} /$ day) in drinking water for 14 weeks. The discrepancy between the present result and of Isaac and Ebenezer (2010) may be due to prolonged exposure of EGME in later studies while in the present study the mice were exposed with EGME only for 10 days. Further, the delayed impaired response as noticed in the present study clearly indicates that EGME not itself but its active metabolite, ethoxyacetic acid, formed as a result of metabolism of EGME, might have exerted oxidative stress 20 days after withdrawal of the treatment. Wang et al., (2006) reported the inhibitory effect of EGME metabolite, ethoxyacetic acid on sperm motility. The delayed expression of acute effects of its other active metabolite, methoxyacetic acid is also well reported (Miller et al., 1982). Induction of stress following EMGE treatment withdrawal again suggest the delayed response of EGME due to its conversion into methoxyacetic acid that might have damaged the spermatozoa which are highly susceptible to ROS because of their high content of polyunsaturated fatty acid, thus impairing the spermatozoal function.

Therefore, significant alterations noticed in the testicular oxidative stress could be correlated with the altered sperm parameters in 20 days treatment withdrawal mice, which clearly indicate the delayed impaired response of the testis to EGME even when administered for 10 consecutive days only. It appears that this toxicant might have retained in the testis, exerting its deleterious effects on the germ cells for several days after administration, the outcome of which is evidenced by significant alterations in the sperm indices. The inhibition of sperm motility, as noticed in the 20 days treatment withdrawal group, is accompanied by signifi- cant decline in the percentage of viable spermatozoa and increase in the percentage of abnormal spermatozoa.

Spermatogenic recovery is generally determined 3-4 weeks after treatment-induced inhibitions. Forty two days withdrawal of EGME treatment in the mice of group III showed significant recovery in the sperm parameters and oxidative stress markers. These recoveries reflect the reversible effects following exposure to EGME.

Since, the EGME adversely affected the epididymal sperm parameters and induced testicular oxidative stress following 20 days withdrawal preceded by 10 days treatment, therefore, it was planned to study the efficacy of root extract of Ws $(100 \mathrm{mg} /$ $\mathrm{kgBW} /$ day) in 10 days EGME-treated mice following its administration from $11^{\text {th }}$ to $30^{\text {th }}$ day. In this supplementation study it was found that, treatment with $W s$ significantly restored the activities of antioxidant enzymes, sperm motility, viability and counts along with significant decrease in the level of testicular MDA and sperm morphological abnormalities. Protective efficacy of $W s$ has also been reported in galactose-stressed mice (Patil et al., 2012) and arsenic-induced testicular toxicity in the rat (Kumar et al., 2015). Reports suggest the antioxidant property of $W s$ is attributed to the presence of Withaferin A (Glycowithanolides) and Sitoindosides VII-X (Bhattacharya et al., 1997; Dhuley, 1998). In addition, the antioxidant efficacy of $W_{S}$ is also attributed to the presence of other compounds such as polyphenols, flavonoids and vitaminC (Visavadiya and Narasimhacharya, 2007; Udayakumar et al., 2010). These compounds have been shown to reduce the levels of lipid peroxidation and oxidation of LDL (Tiwari, 1999; Jovanovic and Simic, 2000) by scavenging the hydroxyl and superoxide anions free radicals. Further, studies have demonstrated the beneficial effects of polyphenols and flavonoids which stimulate SOD and catalase gene transcription, thereby, increasing the antioxidant activities and reducing the lipid peroxidation level (Toyokuni et al., 2003; Ranaivo et al., 2004). Moreover, root enriched with ascorbic acid could readily scavenge ROS and can increase the testicular antioxidant activity, thereby, preventing the lipid peroxidation (Ray and Husain, 2002; Sowell et al., 2004).

On the whole, it is suggested that the potential source of active compounds present in the root extract of $W s$ could have directly scavenged the free radicals, reduced the degradation of antioxidants and increased the biosynthesis of antioxidants through scavenging the excess amount of free radicals, thereby, increasing the bioavailability of antioxidants under oxidative stress conditions. This, further, might have improved the whole anti-oxidants system in the testis and thus the sperm characteristics in the epididymis.

\section{CONCLUSION}

It can be concluded that EGME exposure induces reversible delayed adverse actions through alterations in testicular oxidative stress and sperm indices. Further, the root extract of $W s$ is proved to be useful in preventing testicular oxidative stress and epididymal sperm characteristics. The investigations of molecular responses with $W s$ is required which may assist to elucidate the true impact and overall extent of recovery.

\section{ACKNOWLEDGEMENT}

The first author is thankful to University Grant Commis- 
sion, New Delhi and Banaras Hindu University, Varanasi, for providing financial assistance to carry out the present work.

\section{REFERENCES}

Adedara, IA and Farombi EO. Chemoprotection of ethylene glycol monoethyl ether-induced reproductive toxicity in male rats by kolaviron, isolated biflavonoid from Garcinia kola seed. Hum Exp Toxicol, 2012; 31:506-517.

Adepu S, Devkar RA, Chaudhary S, Setty, MM, Antiurolithiatic activity of Alternanthera tenella Colla in ethylene glycol induced urolithiasis in Rats. Asian J Pharmaceut Sci, 2015; doi: 10.1016/j.ajps.2015.11.003.

Agarwal A, Virk G, Ong C, Plessis SS du. Effect of Oxidative Stress on Male Reproduction. World J Mens Health, 2014; 32: 1-17.

Aitken RJ and Clarkson JS. Cellular basis of defective spermatozoa function and its association with the genesis of reactive of reactive oxygen species by human spermatozoaatozoa. J Reprod and Fertl, 1987; 81:459-469.

Archana R and Namasivayam A. Anti-stressor effect of Withania somnifera. J Ethnopharmacol, 1999; 64: 91-93.

Bagchi, G and Waxman DJ. Toxicity of Ethylene Glycol Monomethyl Ether: Impact on Testicular Gene Expression. Int J Androl, 2008; 31: 269-274.

Bhattacharya A, Ghosal S, Bhattacharya SK. Antioxidant effect of Withania somnifera glycowithanolides in chronic footshock stressinduced perturbations of oxidative free radical scavenging enzymes and lipid peroxidation in rat frontal cortex and striatum. J Ethnopharmacol, 2001;74:1-6.

Bhattacharya SK, Satyan KS, Ghosal S. Antioxidant activity of glycowithanolides from Withania somnifera. Indian J Exp Biol, 1997; 35:236-239.

Boatman RJ. International industry initiatives to improve the glycol ether health effects knowledge base. Toxicol. Lett, 2005; 156:39-50.

Boatman RJ and Knaak JB. 2001. Ethers of ethylene glycol and derivatives. In: Bingham E, Cohrssen B, Powell CA (eds) Patty's Toxicology. Wiley \& Sons 73-270.

Boekelheide K. Mechanisms of toxic damage to spermatogenesis. J Natl Cancer Inst Monogr, 2005; 34:6-8.

Bolleddula J,Yanjum Z, Navindra SP, Muraleedharan NG Growth kinhibition of human tumot cell lines by withanoides from Withania somnifera leaves. Life Sci, 2003;74:125-132.

Chaurasia SS, Panda S, Kar A. Withania somnifera root extract in the regulation of lead-induced oxidative damage in male mouse. Pharmacol Res, 2000; 41:663-666.

Claiborne A. 1985. Catalase activity, In: Greenwald R (ed) CRC Handbook of methods for oxygen radical research, CRC Press, Boca Raton, Fla 283-284.

Davis L and Kuttan G, Effect of Withania somnifera on cell mediated immune responses in mice. J Exp Clin Cancer Res, 2002; 21:585590 .

De Lamirande E, Hong J, Armand Z, Hideya K, Claude Gagnon. Reactive oxygen species and sperm physiology. Reviews of Repro, 1997; 2: $48-54$.

Dhuley JN. Adaptogenic and cardioprotective action of ashwagandha in rats and frogs. J Ethnopharmacol, 70; 57-63: 2000.

Dhuley JN. Effect of ashwagandha on lipid peroxidation in stress-induced animals. J Ethnopharmacol, 1998; 60: 173-178.

Flohe L, Gunzler WA. 1984. Assay of glutathione peroxidase, In: Methods Enzymol., (ed. Packer L.), Academic Press, New York, 105:114121.

Ganzera M, Choudhary MI, Khan IA. Quantitative HPLC analysis of withanolides in Withania somnifera, Fitotherapia, 2003;74:68-76.

Gupta ML, Mishra HO, Kalra A, Khanuja, SPS. Root rot and Wilts a new disease of ashwagandha.[Withania somnifera (L) Dunal.] caused by Fusarium solni. J Medicinal \& Aromatic Plant Sci, 2003; 27: 285-287.
Ilayperuma I, Ratnasooriya RD, Weerasooriya TR. Effect of Withania somnifera root extract on the sexual behaviour of male rats. Asian J Androl, 2002;4: 295-98.

Isaac A Adedara and Ebenezer O Farombi. Induction of oxidative damage in the testes and spermatozoa and hematotoxicity in rats exposed to multiple doses of ethylene glycol monoethyl ether. Human and Exp Toxicol, 2010;29: 801-812.

Ischi T, Matsuki S, Iuchi Y, Okada F, Toyosaki S, Tomita Y, Ikeda Y, Fujii J. Accelerated impairment of spermatogenic cells in SOD1knockout mice under heat stress. Free Radic Res, 2005;39:695-705.

Jaleel CA, Lakshmanan GMA, Gomathinayagam M, Panneerselvam R. Triadimefon induced salt stress tolerance in Withania somnifera and its relationship to antioxidant defense system. South African J Bot, 2008; 74: 126-132.

Johanson G. Toxicity review of ethylene glycol monomethyl ether and its acetate ester. Crit Rev Toxicol, 2000;30:307-345.

Jovanovic, SV and Simic MG. Antioxidants in nutrition. Ann NY Acad Sci, 2000; 899:326-334.

Kumar A, Kumar R, Rahman MS, Iqubal MA, Anand G, Nira PK, Ali M. Phytoremedial effect of Withania somnifera against arsenic-induced testicular toxicity in Charles Foster rats. Avicenna J Phytomed, 2015;5: 355-364.

Lowry OH, Rosebrough NJ, Farr AL, Randall RJ. Protein measurement with the Folin phenol reagent. J Biol Chem, 1951;193: 265-275.

Lulat SI, Yadav YC, Balaraman R, Maheshwari, R, Antiurolithiatic effect of lithocare against ethylene glycol-induced urolithiasis in Wistar rats. Indian J Pharmacol, 2016; 48: 78-82.

Maiorino M, Bosello V, Ursini F, Foresta C, Garolla A, Scapin $\mathrm{M}$, Sztajer H, Flohe L. Genetic variations of gpx-4 and male infertility in humans. Biol Reprod, 2003;68:1134-1141.

Miller RR, Carreon RE, Young, JT, McKennea MJ. Toxicity of methoxyacetic acid in rats. Fundam Appl Toxicol, 1982; 2:158-160.

Marklund S, Marklund G. Involvement of superoxide anion radical in antioxidation of pyrogallol and a constituent assay for superoxide dismutase. Eur J Biochem, 1974; 47: 469-474.

Multigner L, Catala M, Cordier S. et al. The INSERM expert review on glycol ethers: findings and recommendations. Toxicol Lett, 2005;15629-15637.

Okhawa H, Ohishi N, Yagi K. Assay of lipid peroxide in animal tissue by Thiobarbituric Acid Reaction, Anal Biochem, 1979;95: 351-358.

Papa S, Skulachev VP. Reactive oxygen species, mitochondria, apoptosis and aging. Mol Cell Biochem, 1997;174: 305-319.

Patil RB, Shreya RV, Meena MP. Protective effect of spermatogenic activity of Withania somnifera (Ashwagandha) in galactose stressed mice. Annals of Biol Res, 2012; 3:4159-4165.

Prakash J, Gupta SK, Dinda AK. Withania somnifera root extract prevents DMBA-induced squamous cell carcinoma of skin in Swiss albino mice. Nutr Cancer, 2002;42:91-97.

Ranaivo, HR, Rakotoarison, O, Tesse, A, Schott, C, Randriantsoa, A, Lobstein, A, Andriantsitohaina, R. Cedrelopsis grevei induced hypotension and improved endothelial vasodilatation through an increase of $\mathrm{Cu} / \mathrm{Zn}$ SOD protein expression. Am J Physiol Heart Cric. Physiol, 2004;286:H775-H781.

Ray G and Husain SA, Oxidants, antioxidants and carcinogenesis. Indian J Exp Biol, 2002; 40: 1213-1232.

Singh G, Sharma PK, Dudhe R, Singh S, Biological activities of Withania somnifera, Annals Biol Res, 2010;1:56-63.

Sowell J, Frei B, Stevens, JF, 2004. Vitamin C conjugates of genotoxic lipid peroxidation products: structural characterization and detection in human plasma. Proc Natl Acad Sci USA, 2004; 101;17964-17969.

Stough C, Lloyd J, Clarke J, Downey LA, Hutchison CW, Rodgers T, Nathan PJ. The chronic effects of an extract of Bacopa monniera (Brahmi) on cognitive function in healthy human subjects. Psychopharmacol(Berl), 2001;156:481-484.

Takei M, Ando Y, Saitoh W, Tanimoto T, Kiyosawa N, Manabe S, Sanbuissho A, Okazaki O, Iwabuchi H, Yamoto T, Adam KP, Weiel JE, 
Ryals JA, Milburn MV, Guo L. Ethylene glycol monomethyl ether-inducedtoxicity is mediated through the inhibition of flavoprotein dehydrogenase enzyme family. Toxicol Sci, 2010; 118:643-52.

Tiwari A, Natural product antioxidants and their therapeutic potential in mitigating peroxidative modification of lipoproteins and atherosclerosis: recent development. J Med Aroma Plant Sci, 1999; 21:730-741.

Toyokuni S, Tanaka T, Kawaguchi W, Fang NR, Ozeki M, Akatsuka S, Hiai H, Aruoma OI, Bahorun T. Effects of the phenolic contents of Mauritian endemic plant extract on promoter activities of antioxidant enzymes. Free Rad Res, 2003;37:1215-1224.

Turner TT and Lysiak JJ, Oxidative Stress: A Common Review Factor in Testicular Dysfunction J Androl, 2008; 29:488-499.

Udayakumar R, Kasthurirengan S, Vasudevan A, Mariashibu TS, Rayan JJ, Choi CW, Ganapathi A, Kim SC. Antioxidant effect of dietary supplement Withania somnifera L. reduce blood glucose levels in alloxan-induced diabetic rats. Plant Foods Hum Nutr. 2010;65:91-98.

Umadevi P. Withania somnifera dunal (ashwagandha): potential plant source of promising drug for cancer chemotherapy and radiosensitization. Indian J Exp Biol,1996;34:927-932.

Vaithinathan S, Saradha B, Mathur PP. Methoxychlor-induced alteration in the levels of HSP70 and clusterin is accompanied with oxidative stress in adult rat testis, J Biochem Molecular Toxicol, 2008; 23: 29-35.

Valko M, Dieter L, Jan M, Mark TD, Cronin MM, Telser J. Free radicals and antioxidants in normal physiological functions and human disease. The Inter J Biochem \& Cell Bio, 2007; 39:44-84.

Visavadiya NP, Narasimhacharya AV. Hypocholesteremic and antioxidant effects of Withania somnifera (Dunal) in hypercholesteremic rats. Phytomed, 2007;14:136-142.

Wang RS, Ohtani K, Suda M, Nikajima T. Inhibitory effect of ethylene glycol monoethyl ether on rat spermatozoa motion. Ind Health 2006; 44: 665-668.

Watanabe A, Nakano Y, Endo T, Sato N, Kai K, Shiraiwa K. Collaborative work to evaluate toxicity on male reproductive organs by repeated dose studies in rats 27 . Repeated toxicity study on ethylene glycol monomethyl ether for 2 and 4 weeks to detect effects on male reproductive organs in rats. J Toxicol Sci, 2000;25: 259-266.

Wiley FH, Hueper WC, Bergen DS, Bloo, FR. The formation of oxalic acid from ethylene glycol and related solvents. J Ind Hyg Toxicol, 1938; 20: 269-277.

World Health Organization: WHO laboratory manual for the examination and processing of human semen. 5th ed. Geneva, Switzerland: WHO Press 2010; 21-56.

Wyrobek AJ, Bruce WR. Chemical induction of sperm abnormalities in mice, Pro Natl Acad Sci, USA, 1975;72: 4425-4429.

Zaneveld L, Polakoski KL. 1977. Collection and physical examination of the ejaculate. In: Hafez ESE, ed. Techniques of Human Andrology, New York: Elseveir/North Holland Press 147-172.

Zheleva-dimitrova D, Obreshkova D, Nedialkov P. Antioxidant activity of tribulus terrestris - a natural product in infertility therapy. Int $\mathrm{J}$ Pharma and Pharmaceut Sci, 2012; 4:508-511.

\section{How to cite this article:}

Kumar P and Singh P. Delayed response of epididymal sperm characteristics and testicular oxidative stress following EGME exposure: Ameliorating potential of Withania somnifera root extract. J App Pharm Sci, 2018; 8 (01): 122-128. 